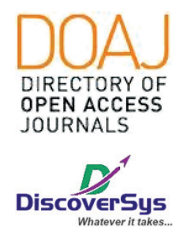

Published by DiscoverSys

\section{Nilai rasio netrofil limfosit dan rasio trombosit limfosit pada pasien chronic kidney disease sebelum dan setelah hemodialisa}

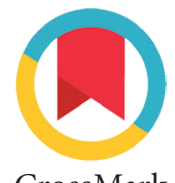

CrossMark

\author{
Nelly,$^{1 *}$ Yuyun Widaningsih, ${ }^{2}$ Fitriani Mangarengi ${ }^{3}$
}

\section{ABSTRACT}

Background: CKD is a world health problem with an increasing incidence, having a poor prognosis and requiring expensive treatment costs. Cardiovascular disease is the cause of high mortality rates in CKD patients due to inflammation. Neutrophil to lymphocytes ratio (NLR) and platelet to lymphocyte ratios (PLR) are considered as inflammatory markers that are cheap, fast and easily calculated from the routine blood examination. This study aimed to know the value of RNL and RTL in CKD patients before and after HD as the initial marker of inflammation.

Method: Eighty-eight patients with CKD were divided into three groups before HD, after the first HD, and after the third HD. The neutrophil-lymphocyte ratio and platelet-lymphocyte ratio are calculated based on the results of routine blood tests. Data distribution was tested with Kolmogorov-Smirnov and analyzed by appropriate data testing.

Results: RNL and RTL values in CKD patients after HD increased compared to before $H D(p<0.05)$. There is a weak correlation between RNL values and serum urea levels. However, the RTL value only correlates with urea before hemodialysis.

Conclusion: There are differences in RNL and RTL values in CKD patients before $H D$, after the first $H D$ and third $H D$. There is a correlation between the RNL value and the state of uremia that is aggravated by HD

Keyword: CKD, hemodialysis, neutrophil to lymphocyte ratio, platelet to lymphocyte ratio Cite This Article: Nelly,Widaningsih, Y., Mangarengi, F. 2019. Nilai rasio netrofil limfosit dan rasio trombosit limfosit pada pasien chronic kidney disease sebelum dan setelah hemodialisa. Intisari Sains Medis 10(2): 230-234. D0I: 10.15562/ism.v10i2.371

ABSTRAK

${ }^{1}$ Program Pendidikan Dokter Spesialis IImu Patologi Klinik, Fakultas Kedokteran Universitas Hassanudin/RSUP dr. Wahidin Sudirohusodo, Makassar, Indonesia ${ }^{2}$ Departemen Ilmu Patologi Klinik Fakultas Kedokteran Universitas Hassanudin/RSUP Universitas Hassanudin, Makassar, Indonesia ${ }^{3}$ Departemen IImu Patologi Klinik Fakultas Kedokteran Universitas Hassanudin/RSUD Syech Yusuf Gowa, Makassar, Indonesia

\section{"Korespondensi:}

Nelly; Program Pendidikan Dokter Spesialis IImu Patologi Klinik, Fakultas Kedokteran Universitas Hassanudin/RSUP dr. Wahidin Sudirohusodo, Makassar, Indonesia; nellymashuri@gmail.com

Diterima: $16-11-2018$

Disetujui: 13-05-2019

Diterbitkan: 01-08-2019
Latar Belakang: Penyakit CKD merupakan masalah kesehatan dunia dengan angka kejadian yang terus meningkat, mempunyai prognosis buruk dan memerlukan biaya perawatan yang mahal. Penyakit kardiovaskular merupakan penyebab tingginya angka kematian pada pasien CKD akibat inflamasi. Rasio Netrofil Limfosit (RNL) dan rasio Trombosit Limfosit (RTL) dianggap sebagai penanda inflamasi yang murah, cepat dan mudah dihitung dari hasil darah rutin. Penelitian ini bertujuan untuk mengetahui nilai RNL dan RTL pada pasien CKD sebelum dan setelah $\mathrm{HD}$ sebagai penanda awal terjadinya inflamasi. Metode: 88 pasien CKD dikelompokkan menjadi kelompok sebelum HD, setelah HD pertama dan setelah HD ketiga. Rasio netrofil limfosit dan rasio trombosit limfosit dihitung berdasarkan hasil pemeriksaan darah rutin. Distribusi data diuji dengan Kolmogrov-Smirnov dan dianalisa dengan uji data yang sesuai.

Hasil: Nilai RNL dan RTL pada pasien CKD berbeda bermakna sebelum HD $(1,96 \pm 0,91)$, setelah HD pertama $(1,87 \pm 0,6)$, dan setelah HD ketiga $(2,11 \pm 0,83)$ dengan $p=0,027$. Adanya korelasi yang lemah antara nilai RNL dan kadar ureum serum. Namun nilai RTL hanya berkorelasi dengan ureum sebelum hemodialisa.

Kesimpulan: Terdapat perbedaan nilai RNL dan RTL pada pasien CKD sebelum HD, setelah HD pertama dan HD ketiga. Adanya korelasi antara nilai RNL dan keadaan uremia yang diperberat dengan HD

Kata Kunci: CKD, hemodialisa, rasio netrofil limfosit, rasio trombosit limfosit

Cite Pasal Ini: Nelly,Widaningsih, Y., Mangarengi, F. 2019. Nilai rasio netrofil limfosit dan rasio trombosit limfosit pada pasien chronic kidney disease sebelum dan setelah hemodialisa. Intisari Sains Medis 10(2): 230-234. D0I: 10.15562/ism.v10i2.371

\section{PENDAHULUAN}

Gagal ginjal kronik atau Chronic kidney disease (CKD) didefinisikan sebagai kerusakan ginjal yang terjadi $\geq 3$ bulan, berupa kelainan struktur atau fungsional dengan atau tanpa disertai penurunan laju filtrasi glomerulus $(\mathrm{GFR})<60 \mathrm{~mL} /$ menit/1,73 $\mathrm{m}^{2}$. Penurunan fungsi ginjal terjadi secara berangsur-angsur dan irreversible yang akan berkembang terus menjadi gagal ginjal terminal. ${ }^{1,2}$

Penyakit CKD merupakan masalah kesehatan dunia dengan angka kejadian yang terus meningkat, mempunyai prognosis buruk dan memerlukan biaya perawatan yang mahal. Berdasarkan data dari 
The United States Renal Data System (USRDS) di Amerika Serikat prevalensi penyakit ginjal kronis meningkat $20-25 \%$ setiap tahun. Insiden CKD di Indonesia diperkirakan $12,5 \%$ atau sekitar 18 juta orang dan di Makassar angka kejadiannya mencapai 100 penderita dari satu juta penduduk . Jumlah penderita CKD yang mendapatkan dialisis dan transplantasi ginjal diproyeksikan meningkat dari 340.000 pada tahun 2009 menjadi 651.000 pada tahun 2015. ${ }^{3,4}$

Mortalitas penderita dengan CKD meningkat 10-20 kali dari populasi normal. Penyakit kardiovaskular merupakan penyebab tingginya angka kematian pada pasien CKD akibat inflamasi yang memainkan peranan penting dalam perubahan morfologi dan fungsional sel endotel vaskular dan epitel tubular pada pasien CKD. Leukosit, termasuk netrofil dan limfosit menginfiltrasi endotel vaskular yang luka termasuk pada ginjal dan menginduksi pelepasan mediator inflamasi seperti C Reaktif protein (CRP), tumor necrosis factor alpha (TNF- $\alpha$ ) dan interleukin (IL)-6 yang ditemukan meningkat pada pasien CKD., ${ }^{5,6}$

Penurunan fungsi ginjal pada uremia meningkatkan risiko terjadinya infeksi dan beberapa abnormalitas pada sistem imun. Terapi dialisis yang berulang juga menyebabkan aktivasi leukosit dan produksi sitokin. Leukosit teraktivasi mengeluarkan berbagai sitokin diantaranya TNF- $\alpha$, TGF- $\alpha 1$, superoxide, NF- $\alpha \mathrm{B}$, monocyte chemoattractant protein-1 (MCP-1), IL-1 $\alpha$, dan sitokin lainnya. Perubahan respon imun pada penderita CKD dapat pula disebabkan akibat defisiensi vitamin $\mathrm{D}$, penimbunan besi yang berlebihan dan akibat tindakan HD. Terjadinya kontak antara darah dengan membran dialisis yang berulang menyebabkan aktivasi sistem komplemen terutama melalui jalur alternatif. Selain itu, terapi dialisis menyebabkan defek pada membran limfosit dan menurunnya masa hidup sel limfosit dalam tubuh sehingga meningkatan resiko pasien terhadap infeksi. Hasil penelitian Ismail dkk. (2013), menyatakan bahwa rasio netrofil limfosit (RNL) merupakan faktor prediktor progresi pada pasien CKD. Kecepatan progresi lebih rendah pada kelompok pasien dengan $\mathrm{RNL} \geq 3$. . $^{1,7,8}$

Selain itu, pada keadaan uremia terjadi gangguan pada fungsi trombosit. Peningkatan produksi prostasiklin meningkat seiring dengan kadar ureum yang tinggi dalam darah. Trombosit merupakan komponen penting pada hemostasis dan berperan dalam terjadinya inflamasi dan imunitas melalui interaksi endotel. Efek gangguan hemostasis memiliki kecendrungan trombositosis pada tahap awal penyakit sedangkan pada tahap lanjut, pasien cenderung mengalami diatesis perdarahan yang diperberat dengan penggunaan heparin yang disebut heparin induced thrombocytopenia (HIT). Pernyataan ini didukung dengan banyaknya laporan gangguan perdarahan pada $40-50 \%$ pasien dengan gagal ginjal kronis setelah hemodialisis berulang minimal tiga siklus. Adhesi trombosit pada endotel memicu leukosit untuk menempel dan berpindah pada endotel yang rusak. Rasio trombosit limfosit (RTL) telah dikenal sebagai penanda inflamasi pada penyakit kardiovaskuler, tumor dan penyakit lainnya., ${ }^{9,10,11}$

Selama 5 tahun terakhir, RNL dan RTL telah diusulkan sebagai marker inflamasi terbaru yang memiliki akurasi baik, murah dan menjadi Pemeriksaan darah yang rutin dilakukan pada pasien CKD baik sebelum dan setelah HD. Namun, masih sedikit penelitian yang menganalisa hubungan antara RNL dan RTL dengan kejadian inflamasi pada pasien HD. ${ }^{12,13}$ Oleh karena itulah, penelitian ini bertujuan untuk mengetahui nilai RNL dan RTL pada pasien CKD sebelum dan setelah HD sebagai penanda awal terjadinya inflamasi.

\section{METODE PENELITIAN}

Penelitian dilakukan secara observasional retrospektif yang dilakukan dengan mengambil data pasien CKD periode Juli 2017 - Juli 2018 di Instalasi Rekam Medik RSUP dr. Wahidin Sudirohusodo Makassar. Sampel adalah semua pasien yang terdiagnosis CKD dan telah mendapatkan terapi hemodialisa serta memiliki hasil pemeriksaan darah rutin dan pemeriksaan ureum kreatinin sebelum dan setelah HD pertama dan ketiga. Pasien CKD yang disertai penyakit DM, HIV dan kardiovaskular serta nilai trombosit $<150.000 / \mu \mathrm{L}$ dieksklusi dalam penelitian ini.

Parameter yang digunakan adalah hasil ureum kreatinin serum, RNL dan RTL sebelum dan setelah HD. Nilai RNL dan RTL merupakan perbandingan nilai netrofil absolut dan limfosit absolut serta perbandingan trombosit dan limfosit absolut yang diperoleh dariberdasarkan hasil pemeriksaan alat automated hematology analyzer metode flow cytometry. Data pasien dikelompokkan menjadi CKD sebelum dan setelah HD pertama dan ketiga.

Analisis data penelitian dilakukan menggunakan piranti lunak statistik SPSS versi 17 dimana hasil penelitian ditunjukkan dalam bentuk rata-rata, simpangan baku, nilai median (minimum-maksimum), maupun analisis statistik dimana dikatakan bermakna apabila Nilai-P diperoleh di bawah 0,05.

\section{HASIL PENELITIAN}

Penelitian ini dilakukan selama 3 bulan dengan jumlah sampel 88 terdiri dari 54 (61\%) laki-laki dan $34(38.6 \%)$ perempuan yang memenuhi kriteria 
Tabel 1 Karakteristik data pasien CKD sebelum dan setelah HD pertama dan HD ketiga

\begin{tabular}{|c|c|c|c|c|c|}
\hline \multirow[b]{2}{*}{ Parameter } & \multirow[b]{2}{*}{$\mathbf{N}(\%)$} & \multicolumn{3}{|c|}{ Pemeriksaan HD (Rata-Rata \pm SB) } & \multirow[b]{2}{*}{ p-Value } \\
\hline & & Sebelum & Setelah HD I & Setelah HD III & \\
\hline \multicolumn{6}{|l|}{ Jenis Kelamin } \\
\hline Laki-Laki & $54(61 \%)$ & & & & \\
\hline Perempuan & $34(38,6 \%)$ & & & & \\
\hline \multicolumn{6}{|l|}{ Umur } \\
\hline 26-35 tahun & $16(18,2 \%)$ & & & & \\
\hline 36-45 tahun & $24(27,3 \%)$ & & & & \\
\hline 46-55 tahun & $25(28,4 \%)$ & & & & \\
\hline$\geq 56$ tahun & $23(26,1 \%)$ & & & & \\
\hline Ureum (mg/dl) & & $206,3 \pm 76,5$ & $132,1 \pm 53,2$ & $91,6 \pm 34,7$ & $0,172^{*}$ \\
\hline Kreatinin (mg/dl) & & $13,37 \pm 6,15$ & $10,03 \pm 8,79$ & $8,63 \pm 3,7$ & 0,002 \\
\hline Leukosit $\left(10^{3} / \mathrm{uL}\right)$ & & $13,03 \pm 8,33$ & $9,60 \pm 4,38$ & $10,54 \pm 5,411,56 \pm 7,2$ & 0,003 \\
\hline Limfosit $\left(10^{3} / \mathrm{uL}\right)$ & & $13,03 \pm 8,3$ & $13,29 \pm 7,6$ & $242, \pm 100$ & 0,015 \\
\hline $\begin{array}{l}\text { Trombosit }\left(10^{3} /\right. \\
\mathrm{uL})\end{array}$ & & $261 \pm 93,2$ & $228 \pm 89,2$ & $11,8 \pm 12,3$ & 0,000 \\
\hline RNL & & $10,7 \pm 12,5$ & $8,1 \pm 5,71$ & $375 \pm 39,2$ & 0,000 \\
\hline RTL & & $283 \pm 22,7$ & $249 \pm 16,2$ & & 0,000 \\
\hline
\end{tabular}

$(\mathrm{P}<0.05)$. Uji korelasi antara ureum dan nilai RNL menunjukkan adanya hubungan yang signifikan $(\mathrm{p}<0.05)$ dengan kekuatan korelasi lemah sedangkan korelasi antara ureum dan nilai RTL hanya berkorelasi sebelum HD

Tabel 2 Perbedaan nilai rasio netrofil limfosit (RNL) sebelum, setelah HD pertama dan setelah HD ketiga

\begin{tabular}{lcccc}
\hline & \multicolumn{3}{c}{ Nilai RNL (n=88) } & Nilai-P \\
\cline { 2 - 4 } Kategori & Median & Min-Maks & Rata-rata \pm SB & $0,027^{\star}$ \\
\hline RNL sebelum HD & 1,84 & $1,39-4,43$ & $1,96 \pm 0,91$ & \\
RNL setelah HD I & 1,92 & $0,20-3,36$ & $1,87 \pm 0,6$ & \\
RNL setelah HD III & 2,01 & $0,70-4,24$ & $2,11 \pm 0,83$ & \\
\hline
\end{tabular}

Keterangan: SB: simpang baku; ${ }^{\star}$ Uji Repeated Anova. Uji Post-Hoc; RNL : Rasio Netrofil Limfosit

Tabel 3 Perbedaan nilai Rasio Trombosit Limfosit (RTL) pada pasien CKD sebelum, setelah HD pertama dan setelah HD ketiga

\begin{tabular}{lcccc}
\hline & & \multicolumn{2}{c}{ Nilai RTL } & P-Value \\
\cline { 3 - 4 } Kategori & N & Median (Minimum-Maksimum) & $0,001^{*}$ \\
\hline RTL sebelum HD & & 5,31 & $1,76-7,26$ & \\
RTL setelah HD I & 88 & 5,36 & $3,70-6,74$ & \\
RTL setelah HD III & & 5,63 & $4,38-7,73$ & \\
& & &
\end{tabular}

Keterangan : ${ }^{*}$ Uji Friedman. Uji Post-Hoc Wilcoxon : sebelum dan setelah HD Pertama $\mathrm{p}<0.05$; sebelum dan setelah HD ketiga $\mathrm{p}<0.05$; setelah HD pertama dan kedua $\mathrm{p}<0.05$. RTL : Rasio Trombosit Limfosit

Tabel 4 Analisis korelasi antara ureum dengan RNL dan RTL pada pasien CKD sebelum dan setelah HD pertama dan setelah HD ketiga

\begin{tabular}{lccccc}
\hline & \multicolumn{2}{c}{ RNL } & & \multicolumn{2}{c}{ RTL } \\
\cline { 2 - 3 } \cline { 5 - 6 } Variabel & $\mathbf{r}$ & $\mathbf{p}$ & & $\mathbf{r}$ & $\mathbf{p}$ \\
\hline Ureum Sebelum HD & 0,281 & $0,008^{*}$ & & 0,227 & $0,033^{* *}$ \\
Ureum Setelah HD I & 0,302 & $0,004^{*}$ & & 0,068 & 0,350 \\
Ureum Setelah HD III & 0,289 & $0,006^{*}$ & & 0,147 & 0,173 \\
\hline
\end{tabular}

Keterangan: $\mathrm{r}$ :korelasi, $\mathrm{P}<0.05$; pearson ${ }^{*}$ dan Spearman rho ${ }^{* *}$ 
inklusi dan eksklusi. Umur terbanyak menderita CKD berkisar antara 46-55 tahun sebesar 25 orang (28.4\%). (Tabel 1). Distribusi data untuk semua parameter tidak normal $(\mathrm{P}<0.05)$ kecuali ureum sehingga dilakukan transformasi data kembali dilakukan uji distribusi data. Distribusi data menjadi normal kecuali untuk parameter RTL tetap berditribusi tidak normal. Uji Repeated Anova yang dilanjutkan dengan uji Post Hoc menunjukkan ada perbedaan bermakna nilai RNL pada pasien sebelum $\mathrm{HD}$, setelah HD pertama dan setelah HD ketiga $(\mathrm{P}<0.05)$. Nilai $\mathrm{RNL}$ semakin meningkat setelah HD ketiga. Uji Friedman yang dilanjutkan dengan uji Post Hoc menunjukkan ada perbedaan bermakna nilai RTL pada pasien sebelum HD, setelah HD pertama dan setelah HD ketiga $(\mathrm{P}<0.05)$. Uji korelasi antara ureum dan nilai RNL menunjukkan adanya hubungan yang signifikan $(\mathrm{p}<0.05)$ dengan kekuatan korelasi lemah sedangkan korelasi antara ureum dan nilai RTL hanya berkorelasi sebelum HD.

\section{PEMBAHASAN}

Penelitian dilakukan pada bulan Juli sampai Agustus 2018 dengan mengambil data rekam medik periode Juli 2017-Juli 2018 di RS.dr. Wahidin Sudirohusodo. Penelitian ini menggunakan desain penelitian cross sectional observasional retrospektif dengan jumlah 88 penderita CKD yang memenuhi kriteria inklusi dan eksklusi. Laki-laki lebih banyak menderita CKD dibandingkan perempuan pada kelompok umur 46-55 tahun. Uji Repeated Anova, menunjukkan adanya perbedaan bermakna antara nilai RNL sebelum dan setelah HD pertama dan ketiga begitupula dengan nilai RTL berbeda signifikan dengan uji Friedman.

Penelitian ini sejalan dengan penelitian yang dilakukan oleh Gulay Ulusal (2013) di Turkey yang meneliti adanya peningkatan RNL pada CKD setelah HD dengan korelasi kuat dengan peningkatan penanda inflamasi. Penelitian yang sama yang dilakukan oleh Turkmen (2012) mendapatkan hasil adanya perbedaan bermakna antara RNL pada pasien CKD sebelum dan setelah HD. ${ }^{8,14}$

Inflamasi mulai terjadi pada stadium awal CKD. Peningkatan leukosit terutama komponen netrofil merupakan prediktor terjadinya penyakit kardiovaskular yang dihubungkan dengan mortality pada pasien HD. Kadar limfosit post HD mengalami penurunan akibat apoptosis limfosit. Darah yang berkontak dengan permukaan membran dialiser selama proses hemodialisis menyebabkan penurunan respon imun tubuh akibat defek pada sel limfosit $\mathrm{T}$ sehingga mudah terjadi infeksi. Perubahan respons imun pada penderita gagal ginjal kronik dapat dikelompokkan menjadi 4 yaitu akibat uremia, akibat defisiensi vitamin $\mathrm{D}$, akibat penimbunan besi yang berlebihan dan akibat tindakan hemodialialisis. RNL merupakan faktor prediktor progresi pada pasien CKD dengan kecepatan progresi lebih rendah pada kelompok pasien dengan $\mathrm{RNL} \geq 3.5$. $^{12,13,14}$

Hasil penelitian kami juga menunjukkan adanya korelasi antara kadar ureum dan RNL dengan nilai $\mathrm{p}<0.05$. Keadaan uremia pada pasien CKD merupakan salah satu faktor yang menyebabkan penurunan imunitas dan dapat dipergunakan dalam memprediksi mortalitas. Begitu pula dengan studi yang dilakukan Prabawa IPY tahun 2019 dimana parameter RNL dan RPL dapat dipergunakan sebagai faktor prediktif pada kanker serviks. ${ }^{15}$ Pada uremia ditemukan peptida yang mirip dengan ubiquitin yang menghambat kemotaksis neutrofil dan menghambat pengikatan sel polimorofonuclear (PMN) dengan molekul C5a sehingga terjadi penurunan fungsi sistem imun. Selain itu, pada keadaan uremia terjadi disfungsi trombosit yang ditandai dengan aktivasi trombosit yang berlebihan seperti peningkatan jumlah trombosit, pelepasan granula alfa dan agregasi trombosit. Baik trombositosis maupun trombositopenia dapat ditemukan pada pasien CKD. Jumlah trombosit> 300 memiliki prognosis kardiovaskular yang lebih buruk dengan tingkat kematian lebih tinggi. Sebaliknya, trombositopenia pada CKD juga sering terlihat. Penurunan jumlah trombosit selama HD disebabkan oleh aktivasi dan granulasi trombosit dan paparan membran dialisis yang menyebabkan agregasi trombosit. Trombositopenia juga dapat disebabkan oleh induksi heparin selama dialisis. ${ }^{12,13}$

Pada penelitian kami ditemukan adanya perbedaan RTL sebelum dan setelah HD dengan jumlah trombosit setelah HD ketiga lebih tinggi daripada HD pertama meskipun jumlahnya masih dalam batas normal. Dalam penelitian ini juga tidak ditemukan adanya korelasi signifikan antara uremia dengan RTL setelah HD. Hal ini mungkin disebabkan karena jumlah trombosit pasien masih dalam batas normal dan belum menunjukkan adanya disfungsi trombosit dan kerusakan endotel. Gangguan hemostasis memiliki kecendrungan trombositosis pada tahap awal penyakit sedangkan pada tahap lanjut, pasien cenderung mengalami diatesis perdarahan yang diperberat dengan penggunaan heparin yang disebut heparin induced thrombocytopenia (HIT). ${ }^{13,14}$

\section{SIMPULAN}

Penelitian ini menunjukkan adanya perbedaan antara perbandingan RNL dan RTL pada pasien 
CKD sebelum dan setelah HD. Perbedaan ini terjadi terutama pada RNL sebelum dan setelah HD ketiga. Selain itu, adanya korelasi antara RNL dengan kadar ureum dan tidak ada korelasi antara kadar ureum dan RTL setelah HD.

\section{ETIKA PENELITIAN}

Penelitian ini Telah Mendapatkan Persetujuan dari Komisi Etik Penelitian Kesehatan FK Universitas Hasanuddin RSUP dr. Wahidin Sudirohusodo Makassar, Indonesia.

\section{KONFLIK KEPENTINGAN}

Tidak terdapat konflik kepentingan dalam penulisan laporan akhir penelitian ini.

\section{PENDANAAN}

Penulis bertanggung jawab terhadap pendanaan penelitian tanpa melibatkan sumber dana dari sponsor ataupun grant penelitian.

\section{KONTRIBUSI PENULIS}

Seluruh penulis memiliki kontribusi yang sama dimana meliputi penyusunan proposal penelitian, pengambilan data, analisis data, maupun penyajian laporan hasil akhir penelitian.

\section{DAFTAR PUSTAKA}

1. Atziza R, Ayu PR, Yonata A. Perbedaan kadar limfosit pre dan post hemodialisis pasien gagal ginjal kronik. Medula. 2017; 7(4):37-41.

2. Kaparang J, Moeis ES, Rotty L. Nilai trombosit pada pasien penyakit ginjal kronik yang menjalani hemodialisis di unit hemodialisis bagian/smf ilmu penyakit dalam FK UNSRAT BLU RSUP Prof. Dr. R. D. Kandou Manado. Jurnal e-Biomedik (eBM). 2013; 1(1):95-100.

3. American Journal of Kidney Diseases. Chapter 1: Incidence, Prevalence, Patient Characteristics, and Treatment Modalities. PlumX Metrics. 2015; 66(1) (Suppl1):S93-S110.

4. Jha V, Garcia-Garcia G, Iseki K, Li Z, Naicker S, Plattner B, et al. Chronic kidney disease: global dimension and perspectives. Lancet. 2013; 382(9888):260-72.
5. Kocyigit I, Eroglu E, Unal A, Sipahioglu $\mathrm{MH}$, Tokgoz B, Oymak $\mathrm{O}$ et al. Role of neutrophil/lymphocyte ratio in prediction of disease progression in patients with stage-4 chronic kidney disease. Journal Nephrology. 2013; 26(02): 358-65.

6. Garcia MF, Wazlawik E, Moreno YMF, Führ LM, González-Chica DA. Diagnostic accuracy of handgrip strength in the assessment of malnutrition in hemodialyzed patients. e-SPEN Journal. 2013: 181-86.

7. Tbahriti HF, Meknassi D, Moussaoui R, Messaoudi A, Zemour L, Kaddous A, Dkk. Inflammatory status in renal failue: the role of homocysteinemia and proinflammatory cytokines. World J Nephrol. 2013; 2(2):31-7.

8. Okyay GU, Inal S, Oneç K, et al. Neutrophil to lymphocyte ratio in the evaluation of inflammation in patients with chronic kidney disease. Ren Fail. 2013; 35:29-36.

9. Kato A, Takayuki Tsuji, Yukitoshi Sakao, et all. A Comparison of Systemic Inflammation-Based Prognostic Scores in Patients on Regular Hemodialysis. Blood Purification Unit, Hamamatsu University Hospital. Nephron Extra. 2013 ;3(1):91-100.

10. Pusparini. Perubahan respons imun pada penderita gagal ginjal kronik yang menjalani hemodialysis. J Kedokter Trisakti. 2000; 19(3):115-124.

11. Zheng, Chen-Fei, Wen-Yue Liu, et all. Prognostic Value of Platelet-to-Lymphocyte Ratios among Critically Ill Patients with Acute Kidney Injury. Crit Care. 2017; 21(1):238.

12. Tucker PS, Scanlan AT, Dalbo VJ. Review Article Chronic Kidney Disease Influences Multiple Systems: Describing the Relationship between Oxidative Stress, Inflammation, Kidney Damage, and Concomitant Disease. Oxidative Medicine and Cellular Longevity Hindawi Publishing Corporation. 2015: 1-8.

13. Azab B, Camacho-Rivera M, Taiol E. Average Values and Racial Differences of Neutrophil Lymphocyte Ratio among a Nationally Representative Sample of United States Subjects. PLoS ONE. 2014; 9(11): 1-6.

14. Turkmen K, Ibrahim Guney, etc. The Relationship Between Neutrophil-to-Lymphocyte Ratio and Inflammation in Enda Stage Renal Disease Patients. Department of Nephrology, Selcuk University Meram School of Medicine, Konya, Turkey. Renal Failure. 2012; 34(2): 155-159.

15. Prabawa IPY, Bhargah A, Liwang F, Tandio DA, Tandio AL, Lestari AAW, Budiana ING, Manuaba IBAP. Pretreatment Neutrophil-to-Lymphocyte ratio (NLR) and Platelet-to-Lymphocyte Ratio (PLR) as a Predictive Value of Hematological Markers in Cervical Cancer. Asian Pac J Cancer Prev. 2019; 20(3):863-868.

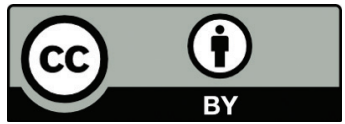

This work is licensed under a Creative Commons Attribution 